\title{
Embedding Literacy Strategies in Social Studies for Eighth-Grade Students
}

\author{
Alishia Gaston ${ }^{1}$, James Martinez ${ }^{2}$ \& Ellice P. Martin ${ }^{3}$
}

\begin{abstract}
This action research study evaluated the effects of literacy strategies on academic achievement, motivation, and engagement of eighth-grade social studies students. Incorporating literacy strategies included teaching students to construct meaning, think critically, and build content knowledge, while stimulating their interests, using multiple texts and technology, and providing collaborative opportunities and high engagement during instructional activities. Students were divided into a literacy group and a direct instruction group with each class being taught the same content. Literacy strategies were incorporated in one class, and direct instruction activities were used in the other class. Results were determined using pre and posttest scores, a student motivation questionnaire, and a student engagement checklist. Results indicated significantly higher student achievement and engagement when literacy strategies were a part of the social studies instruction. Motivation also increased when literacy strategies were used. Literacy instruction was a beneficial strategy to improve student achievement, motivation, and engagement.
\end{abstract}

Keywords: Literacy strategies, sandardized testing, social studies, middle school

\section{Introduction}

Literacy is deeply woven into the fabric of successful social studies classes and can be used successfully to provide accommodations and modifications for diverse learning needs (Lindsay \& Horn, 2011; Parr \& Campbell, 2012; Soares \& Wood, 2010). Students often enter social studies classes having predetermined they will not pass, they will not like the class, or they will not view the class as beneficial. Some students may have no idea how social studies or history can benefit them in the future. Simultaneously, students know they must pass the Social Studies portion of the Georgia state content test, titled the Criterion Referenced Competency Test (CRCT), and they must pass their eighth-grade social studies course, which is a course in Georgia Studies, to meet requirements for promotion to the ninth grade. Despite these realities, consistently low scores on state-mandated tests (Governor's Office of Student Achievement, 2011) and students voicing preconceived notions about social studies alerted both teachers and students at the research site that something was missing in the social studies instruction.

\footnotetext{
1 Teacher, Lonwdes County Schools, alishiagaston@lowndes.k12.ga.us

${ }^{2}$ Assoc. Prof., Valdosta State University, jammartinez@valdosta.edu

${ }^{3}$ Prof. Dr., Valdosta State University, epmartin@valdosta.edu
} 
Journal of Social Studies Education Research 2016: 7(1), 73-95

There is no magic elixir for students' lack of motivation, engagement, and achievement in social studies, but literacy strategies were seen as a help that teachers might use to pique students' interest and help them succeed. The incorporation of literacy strategies into instruction can be a tool for teachers to address achievement for the diverse learning modalities and learner preferences in their classrooms (Santamaria, Taylor, Park, Barett, \& Van der Mandele, 2010).

Literacy has become much more than just the ability to read the written word (Alberta Education, 2008). Definitions of literacy have continued to evolve and parallel changes in society, culture, and education. The definitions have come to encompass traditional or direction instruction descriptions of literacy skills as well as more of the broadly defined standards for the $21^{\text {st }}$ century- learner, and literacy is not limited to vocabulary acquisition, library and reference skills, reading strategies, and knowledge and skill transfer from one context to another. Teaching students to become independent thinkers and learners who can remember and reuse what they have read to gather meaning, think critically, and solve problems is part of literacy, which involves not only reading, but speaking, listening, viewing, and understanding all forms of communication (Gross, 2010). Gross affirmed that literacy is a means for broadening teachers’ instructional repertoires and student engagement, ensuring students connect ideas across academic disciplines, and ensuring students connect content to their life experiences. In recent years, Gross noted, the concept of literacy has come to encompass how students comprehend and convey meaning through technology and web-based texts.

One of the main goals of literacy instruction is to help students develop the ability to think deeply about content material and communicate effectively about learned concepts, and another is to equip students to use the abundance of information they are presented and apply that information to various settings (Alberta Education, 2008).

Integration of literacy and social studies can be critical for student success (Kent \& Simpson, 2008; Parr \& Campbell, 2012). Social studies learning is promoted through the use of critical literacy perspectives when learning tasks include opportunities for interaction with various modes of text, discussion, critical thinking, and engagement in real world activities (Soares \& Wood, 2010). Embedding literacy to improve social studies achievement includes teaching to improve students' understanding of content, improve critical thinking, foster student motivation, increase student engagement, create strong content readers and writers, and improve vocabulary. Key, Bradley, J., and Bradley (2010) declared that in order to stimulate students’ 
interest in social studies and promote literacy, students must be actively involved. They also affirmed the reciprocal nature of social studies and literacy by which motivation is linked to engagement (Key et al., 2010).

Effectively embedding literacy in social studies includes using reading comprehension strategies, including vocabulary acquisition and development strategies, using web-based tools, incorporating non-traditional texts, building contextual knowledge, examining multiple perspectives, and expanding the depth and quality of teachers by building their confidence. According to Kent and Simpson (2008), literacy strategies can be used in social studies to enforce reading skills students will need throughout their lives.

Research focusing on literacy also includes work by Reed (2009), who expressed an increased concern about literacy needs of young adults as well as challenges for teachers who stress reading across the curriculum. In the same manner, Damico, Baildon, Exter, and Guo (2009) noted guiding students to become strategic readers in disciplines such as mathematics, science, and social studies comes with many challenges.

Many researchers describe increased literacy as the best way to improve all students' learning. Bayer and Staley (2003) suggested literacy will be the most effective tool for eradicating poverty and sustaining the healthy development of children and families in any country because strategies will help students find ways to work through and communicate their hopes, fear, and dreams as well understand other cultures and the world around them.

From a teacher's perspective, students struggle with social studies because they are uninterested or unable to comprehend contextual information and make it relevant to their lives. Some students simply do not understand the importance of social studies content and cannot make connections between what has happened and how it has shaped what is happening on global, state, and local levels. Social studies is often deemed boring and filled with too many dates and people to remember.

At the research site, more than 100 of the 314 students in the eighth grade did not pass the 2011 Criterion Referenced Competency Test (CRCT) (Governor's Office of Student Achievement, 2011). Less than two-thirds of all Georgia Studies students at the site met proficiency levels, and very few exceeded achievement levels. According to the school improvement plan for the research site, only 53\% of all eighth-grade students met requirements to pass the Social Studies portion, and only $15 \%$ scored in the category for exceeding 
expectations. The test results warranted much consideration and reflection by teachers and administrators about what could be done to improve student achievement in social studies overall without focusing merely on test-taking strategies. There was an obvious need to help students see content material as more than a series of stories about people, events, and places from the past. Key et al. (2010) suggested that students can be forced to complete an assigned task, but they cannot be compelled to learn effectively or to care about what they are learning.

The school improvement plan for the research site included goals for improving eighthgrade social studies test scores. The first goal was simply to have more students pass the Social Studies portion of the CRCT. The second goal was to move more students from the meets to exceeds category to show not only mastery of content material but also extended learning and understanding. In addition, one aspect of the school improvement plan focused on student motivation and engagement. Soares and Wood (2010) affirmed a good curriculum involves planning for student conversation to allow engagement in real world activities. The principal, leadership team, and teachers in this professional learning community made a commitment to keep students actively involved at all times.

"In response to the pressure that schools face to produce students who are literate members of society, the current mantra of accountability and high stakes testing has forced teachers to reconsider the best means for teaching social studies content” (Soares \& Wood, 2010, p. 488). Pressure about student performance on high stakes tests has compelled teachers to tailor instruction to parallel student interest and accommodate for changes with technological advancements. Social studies teachers can no longer contemplate whether or not to incorporate literacy strategies. They must be able and willing to meet students' literacy needs while simultaneously meeting content performance objectives.

\section{Review of the Literature}

Parr and Campbell (2012) believed it is essential that literacy strategies and skill instruction be purposefully and appropriately planned and embedded within social studies instruction. Many teachers face challenges trying to integrate literacy into the curriculum, and some of those challenges include lack of ability, lack of confidence, lack of resources, and lack of training. Gross (2010) wrote that this change in instructional practices and focus requires teachers to experiment with new approaches while still meeting academic discipline demands. 
According to Hagood, Provost, Skinner, and Egelson (2008), teachers may lack the ability to effectively implement literacy strategies without compromising important parts of the social studies curriculum. Santamaria et al. (2010) declared bolstering teachers' confidence and competence with the use of literacy strategies is essential to effective integration into instructional activities. Reed (2009) suggested that while literacy demands in the workplace, military, college, and citizenship have been increasing, materials and instruction seemingly have not kept pace or focused on keeping students motivated to learn.

In a two-year study of social studies classes with 41 students at two low-performing middle schools (grades 6-8), Hagood et al. (2008), examined teachers' and students' understandings and uses of literacy. They noted although teachers were excited about new literacy strategies and were introduced to new strategies, they had difficulty implementing them in instruction and often viewed literacy in a traditional, direct instruction manner. Damico et al. (2009) believed content area teachers often resist responsibility for reading and literacy instruction and think literacy instruction is the sole responsibility of reading teachers. Some continue to rely on ineffective methods to present content information.

Strong professional development should include opportunities to experience literacy strategies from a student's perspective, to see examples that are relevant to teachers' unique classrooms, and to work with literacy coaches while integrating strategies into their lesson plans (Santamaria et al., 2010). Gross (2010) endorsed the practice of using literacy coaches to assist teachers as they take advantage of the multiple modes of literacy and learning that stimulate student curiosity, promote inquiry, and generate critical problem-solving.

Some students struggle in social studies because they are disengaged, disinterested, and disconnected from classroom instruction. When students have the opportunity to bring their life experiences into the classroom, and teachers provide instructional activities for students to examine multiple perspectives and plan for student conversation allowing engagement in realworld activities, high levels of engagement are fostered (Soares \& Wood, 2010). Literacy strategies allow students to engage with relevant reading materials from varied sources including current events and reading materials written from varied perspectives and for various purposes.

Social studies is a discipline that requires a great deal of reading. Kent and Simpson (2008) claimed literacy and social studies instruction can be integrated in meaningful ways such as posing questions to students about the world in which they live, allowing opportunities for 
writing about relevant experiences in their own lives, and using gateways to get the students thinking about the basic concept behind what they are studying in order to meet the challenge of increasing both reading achievement and content knowledge. Key et al. (2010) suggested student interest is stimulated by involvement with content during prereading, guided reading, and post-reading activities, and that these activities provide students with opportunities for comprehension.

According to Kent and Simpson (2008), such strategies helped students effectively comprehend content material and allowed them to make connections, ask questions, make inferences, engage in critical thinking, and differentiate between key ideas and less important information. This comprehension occurred in a social studies class that used websites on Nazi Germany to teach students about the impact of the Holocaust on the world. In a first-grade classroom in the teacher-researcher's school district, a teacher used literacy strategies to teach about the American flag and emphasize patriotism. The teacher opted not to use the course text and rather chose a book from the student class library. Important key words and vocabulary for understanding the text were identified, and a concept map was used to help students organize new information and distinguish between significant and less important ideas.

Kent and Simpson (2008) argued vocabulary is critically linked to comprehending social studies content. Social studies texts have technical vocabulary that can be challenging for students; therefore, opportunities for vocabulary acquisition and concept learning are vital. Santamaria et al. (2010) believed some strategies such as word maps and vocabulary webs, often used at the beginning of a lesson, helped students improve vocabulary, while others such as jigsaw and think-pair-share focus on summarizing information and are often used at the end of a lesson.

In recent years, the concept of literacy has come to encompass how students comprehend and convey meaning through technology and web-based texts (Bean \& Dagan, 2011). Across academic disciplines, the practice of learning through literacy has increased as digital texts, WebQuests, online tutorials, and interactive websites have transformed direction instruction approaches to teaching and learning.

Soares and Wood (2010) affirmed literacy and content converge in social studies courses with the goal of developing in students the capacity for critical thinking within a global society. Today’s socials studies classes offer many opportunities for content teachers to make learning 
relevant, provide engaging instruction, and draw on personal experiences from students' lives that have been fashioned by cultural, societal, and economic influences and have been transformed by technology, information, and social media.

\section{Purpose of the Study}

The purpose of this study was to examine the effects that incorporating literacy strategies in social studies would have on student achievement, motivation, and engagement compared to the effect of those variables of direct instruction. As a teacher, the researcher could use data from this study to make informed decisions about how to tailor instruction to meet students' diverse learning needs. Results from the study have the potential to help other content teachers and to help administrators, department heads, academic coaches, and curriculum directors when considering changes in social studies curriculum and appropriate professional learning workshops for teachers. Additional research would have important implications for educators with the implementation of new state performance standards and could help teachers draw objective conclusions about how to most effectively teach the new standards.

\section{Research Questions}

Research question 1. Will incorporation of literacy strategies into instruction improve student achievement in social studies compared with student achievement after direct instruction?

Research question 2. Will incorporation of literacy strategies improve student motivation during social studies instruction compared to student motivation during direct instruction?

Research question 3. Are students more engaged when teachers use literacy strategies to teach social studies content compared to student motivation during direct instruction?

\section{Definition of Variables}

Literacy strategies. Literacy strategies allow students to interact with a variety of texts, to view content from multiple perspectives, and to use their prior knowledge along with clues from the text to construct meaning. In this study, literacy strategies included the incorporation of webbased tools within lessons before, during, and after reading and vocabulary instruction.

Direct instruction. Direct instruction was used for comparison of achievement using that strategy to achievement with the inclusion of literacy strategies. The teacher-directed instruction 
Journal of Social Studies Education Research 2016: 7(1), 73-95

involved students reading from a social studies textbook and completing worksheets. Direct instruction was used to introduce new content with vocabulary definitions and other key terms.

Achievement. In this study, achievement was a measure of the skills, knowledge, and concepts a student had learned and retained at the culmination of an instructional unit. The skills, knowledge, and concepts reflected students' aptitude and ability to meet content performance objectives. Achievement was measured using questions from the Georgia Online Assessment System test bank. The test bank was a pool of questions from common assessments on specific topics and from Georgia's statewide assessment, called the Criterion Referenced Competency Test (CRCT).

Motivation. Motivation is the desire to achieve a goal such as meeting social studies performance objectives, combined with energy to work toward that goal. Motivation was measured using responses from a student questionnaire.

Engagement. Engagement was defined in this study as the students' on-task behavior and participation in instructional activities, and was measured using an engagement checklist. The checklist was used to record students’ active and willful involvement in learning activities.

\section{Methods}

\section{Setting and Participants}

This research study took place at a middle school in one of southern Georgia's largest school districts. The population in 2010 for the county was estimated at 109,000 and about 22\% of the population lived below the poverty line. The study, therefore, took place in an economically challenged school district. The school served grades 6 through 8 and had a school population of 905 students (Governor’s Office of Student Achievement, 2011).

The participants were eighth-grade students $(N=43)$ in two Georgia Studies classes from the research site. One class $(n=24)$ was randomly selected and designated the Literacy Instruction Group, and literacy strategies were incorporated in instruction. The other class $(n=$ 19) formed the Direct Instruction Group. The average age for this population of students was 13. Students were randomly assigned to classes, and the student populations of both groups were comparable in terms of academic achievement. 
The achievement characteristics of the population were derived from the previous year's Criterion Referenced Competency Test (CRCT) scores. A student who scored 800 met the standard for achievement in social studies. A score of 800 was considered passing, and scores on the Social Studies portion ranged from 745 to 950. Students identified as Level One (those who did not pass the CRCT in 2012) in Georgia Studies accounted for 31\% of the sample population. Further demographic characteristics of the population are shown in Table 1.

Table 1

Demographic and Achievement Data of Participants

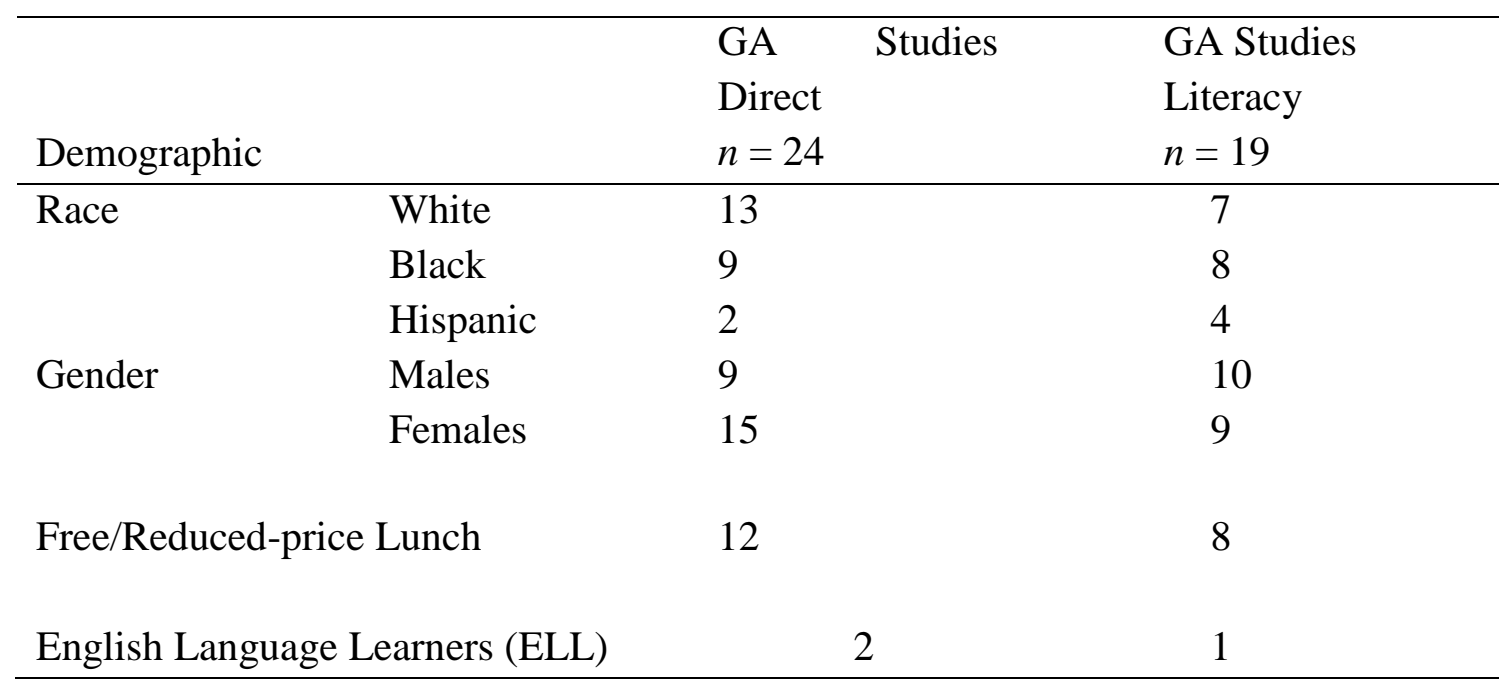

The teacher-researcher, the only adult participant in this action research study, taught the lessons and administered assessments. She was in her 12th year of teaching and was certified in Social Studies, English, and Reading for Middle Grades as well as in Secondary English Education. Ten years of her teaching experience were at the middle school level.

\section{Intervention}

The intervention consisted of a 9-week research period at the beginning of the school year, during which one 50- minute Georgia Studies class was taught using literacy strategies and the other was taught with direct social studies strategies. The same teacher-researcher taught both classes with no co-teachers or paraprofessionals. A unit in Georgia Studies was taught to both classes. The same standards, performance objectives, and assessments were part of achievement expectations for both classes. An identical pretest was administered to both groups prior to Week 1 of the study. The intervention variable for this study was the method of 
instruction used to teach the unit. The teacher used a listing of important people and terms and discussed unit standards and learning objectives for both classes at the beginning of the unit. Students in each group received the same amount of time on task and completed the same required assignments. The groups were compared in terms of how literacy strategies impacted the overall achievement, attitude, and motivation of the groups.

Students in one class were taught using direct teacher-centered strategies and direct instruction. Direct strategies included the teacher-researcher using direct lecture, vocabulary definitions, the textbook, and worksheets as the main resources to present content information. Student participation included note-taking, answering questions orally, completing worksheets, and reading from the textbook. Students also worked in groups to research important topics and historical figures and presented the information to the class. During the study, the teacherresearcher lectured on topics in the social studies curriculum and assisted students as they completed questions from the CRCT Test Prep workbook (Blankenship \& Wood, 2009).

As students progressed through the unit lessons, the teacher-researcher reviewed important vocabulary by making sure students had written the correct definitions in their notebooks. At the end of the unit, the teacher-researcher reviewed important people and events, and students answered true-false questions about those persons and events. Weekly formative assessments such as reading check questions, homework checks, and quizzes were used to help students and the teacher monitor progress, understanding of particular topics, and familiarity with important historical figures and events. Direct strategies such as K-W-Ls (before), ThinkPair-Share (during), and Ticket-Out-the-Door (after) were used. These students made an outline to take notes and learn about important concepts. Their interaction with text was through oral class reading. New vocabulary words were taught using term and definition lists.

For the Literacy Class, the researcher incorporated literacy strategies into instruction. Active literacy strategies included using before, during, and after reading strategies for learning new vocabulary terms and comprehending text, as well as using Frayer models and word maps to take notes and learn about important concepts. Specific passages from the text were given to students, and they interacted with the text by marking the margins with words and ideas that occurred as they were reading with partners. Students also highlighted important ideas, terms, and dates, and they analyzed text structures. The teacher-researcher taught new vocabulary using Marzano and Pickering’s (2005) Six Step Process for Building Academic Vocabulary. For 
weekly formative assessments, students chose from a menu of activities to show their mastery of unit concepts. The menu included summarizing activities such as acrostic poems, Three Facts and a Fib, 3-2-1, Which One Doesn’t Belong?, and Alphabet Soup.

Both groups were given a mini-assessment halfway through the research period and were given a posttest after week 9 of the intervention. Although different methods were used to present the same content information, both groups took the same tests. Questionnaires were given to both groups simultaneously before and after the intervention. Engagement Checklists were completed by both groups after the intervention.

\section{Data Collection Techniques}

The teacher-researcher used several data collection instruments to determine whether the incorporation of literacy strategies improved the achievement, motivation, and engagement of eighth-grade Georgia Studies (social studies) students.

Unit One: Geography, Colonization, and Exploration Test. The Georgia Geography, Exploration, and Colonization (GCE) Test contained 20 multiple-choice items that assessed students' understanding of the geography, Native American exploration, and British colonization in Georgia. The questions were taken from the Georgia CRCT Test Prep Workbook (Blankenship \& Wood, 2009), which was used to help students better prepare for tests. The content validity of this test was established by peer review of three content teachers as well as through the publisher. It was administered to students in both groups, and a score was recorded before and after the intervention. Descriptive and inferential statistics were used to analyze data. Pretest and posttest scores for both groups were analyzed by interpreting the results of unpaired one-tailed $t$-tests to compare the change in means from the pretest to the posttest.

Student Motivation Questionnaire. The Student Motivation Questionnaire (SMQ) was a 10-item Likert-scale survey measuring students’ levels of motivation during their Georgia Studies class. Student responses ranged from 1 (strongly disagree) to 5 (strongly agree). This survey was developed by the teacher-researcher and administered to all students in the study before and after the intervention. Construct validity was established through peer review by three Georgia Studies teachers and one academic coach. The information was analyzed by comparing responses to determine any differences in attitudes of students in the two groups following the intervention. 
Student Engagement Checklist. The Student Engagement Checklist (SEC) was a 10-item checklist that students completed at the end of the study. The survey was designed by the teacher-researcher, and students rated themselves on their levels of engagement. Construct validity was established by pilot testing with 23 participants, and revisions were made based on their input. All students completed the checklist after the intervention, and descriptive statistics were used to analyze data. Results were interpreted by identifying patterns for subgroups of students and discussing emergent themes in data.

Fieldnotes. During this study, the teacher-researcher used a journal to make anecdotal notes about student performance, test scores, levels of engagement, attitudes, and student interest. Additionally, the journal was used to make notes about discipline and potential limitations of the study. Data from fieldnotes were analyzed by coding and then determining any themes related to the research questions.

\section{Results}

The purpose of this research was to ascertain the effectiveness of literacy instruction on achievement, motivation, and engagement in eighth-grade Georgia Studies classes. Data collection provided relevant information to achievement, motivation, and engagement of a direct instruction Georgia Studies class with a literacy strategies Georgia Studies class. Both classes were taught the same information based on state performance objectives by the same teacherresearcher; however, one class had specific literacy strategies embedded into instruction. The data collection instruments included a unit test (GCE Test), which served as the pretest and posttest, a student motivation questionnaire, and an engagement checklist. Results of this study are based on analyses of these data.

To determine the effectiveness of literacy instruction on student achievement, a pretest on Georgia Studies content was administered to both the direct and literacy classes at the beginning of the study. This same test also served as the posttest administered at the conclusion of the intervention. Means and standard deviations of the pretests given in each class are given in Table 2. The mean pretest score for students in the Literacy class $(M=59.38, S D=11.73)$ was not significantly different $(t(41)=-1.10, p=0.14)$ from the mean pretest grade for students who took the pretest in the Direct Instruction class. The classes were similar enough for comparison. 
Table 2

Comparison of Achievement on Pretest Results

\begin{tabular}{|c|c|c|c|c|c|}
\hline Class & $n$ & $M$ & $S D$ & $t$-value & $p$ \\
\hline Literacy & 24 & 59.38 & 11.73 & -1.10 & 0.14 \\
\hline Direct & 19 & 63.16 & 10.45 & & \\
\hline
\end{tabular}

Means and standard deviations for achievement on the posttest administered after the intervention are shown in Table 3. The mean posttest score for the Literacy class $(M=86.46, S D$ = 8.66) was significantly higher than the mean posttest score $(M=75.53, S D=10.53)$ for the Direct Instruction class. Students in the Georgia Studies class receiving literacy strategies scored significantly higher on the posttest than students receiving direct instruction in a Georgia Studies class.

Table 3

Comparison of Achievement on Posttest Results

\begin{tabular}{llllll} 
Class & $n$ & $M$ & $S D$ & $t$-value & $p$ \\
\hline Literacy & 24 & 86.46 & 8.66 & 3.74 & $<.001$ \\
\hline
\end{tabular}

$\begin{array}{llll}\text { Direct } & 19 & 75.53 & 10.53\end{array}$

There was a significant difference in the mean posttest scores (see Table 3 ) of the students in the literacy class compared to the mean posttest scores for students in the direct class. The intervention had a very large effect $(d=1.18)$. An average student (at the 50th percentile) in the Literacy class would be expected to score at about the 86th percentile of students in the Direct Instruction class. Using literacy strategies increased average posttest scores by 14\%.

To adjust for differences in the mean pre-intervention scores for the two classes, the pretest/posttest was used to determine students' knowledge of eighth-grade Georgia Studies content before and after the intervention. A comparison of mean gains for each class is shown in Table 4. The pretest mean for the literacy class $(M=59.38)$ was slightly lower than the pretest mean for the direct class $(M=63.16)$. The posttest mean for the literacy class $(M=86.46)$ was 
Journal of Social Studies Education Research 2016: 7(1), 73-95

higher than the posttest mean for the direct class $(M=75.53)$. The mean gain for the literacy class was significantly greater than the mean gain for the direct instruction class.

Table 4

Comparison of Mean Gains for Achievement

\begin{tabular}{llllll}
\hline Class & Pretest & Posttest & \multicolumn{4}{l}{ Comparison of Mean Gain } \\
\hline & $M$ & $M$ & Gean & & \\
& & & & & \\
& & & & & \\
Literacy & 59.38 & 86.46 & 27.08 & 3.11 & 0.002 \\
\hline & & & & & \\
Direct & 63.16 & 75.53 & 12.37 & & \\
\hline
\end{tabular}

Students participating in the study completed a questionnaire measuring their motivation during Georgia Studies class. Table 5 shows the results from the literacy class questionnaires administered before and after the intervention. The number of students out of the literacy class $(N=24)$ who agreed, were undecided, or disagreed are recorded in Table 5. Statements reflect levels of motivation during instructional activities. The results of the Student Motivation Questionnaire from the literacy class showed distinct differences in the number of students agreeing with statements before and after the intervention. The results indicate that after the intervention, nearly all students agreed with positive statements related to motivation during GA Studies instruction. In some cases, all students agreed with the statements after the intervention, and this result was indicative of increased levels of motivation.

Before the intervention, only half of the literacy class thought learning was interesting and fun, and only 8 students could relate to what was being taught. After the intervention, however, all of the 24 students thought learning was interesting and fun and deemed content material as relevant. All 24 students indicated they learned through the various kinds of activities as well as looked forward to earning good grades. In the same manner, nearly all students indicated they were confident and eager to learn more about their state and were excited to complete projects and assignments. The number of students disagreeing with statements about motivation before the incorporation of literacy strategies decreased considerably after the intervention. 
Table 5

Questionnaire Results for Literacy Group

\begin{tabular}{|c|c|c|c|c|c|c|}
\hline \multirow[b]{2}{*}{ Statements } & \multicolumn{3}{|c|}{ Before Intervention } & \multicolumn{3}{|c|}{ After Intervention } \\
\hline & Agree & Neutral & Disagree & Agree & Neutral & Disagree \\
\hline Learning is interesting and fun. & 12 & 5 & 7 & 24 & 0 & 0 \\
\hline $\begin{array}{l}\text { I can relate to what is being } \\
\text { taught. }\end{array}$ & 8 & 4 & 12 & 24 & 0 & 0 \\
\hline I am focused and interested. & 6 & 9 & 9 & 18 & 3 & 3 \\
\hline $\begin{array}{l}\text { I can learn through various } \\
\text { kinds of activities. }\end{array}$ & 15 & 6 & 3 & 24 & 0 & 0 \\
\hline $\begin{array}{l}\text { I am confident and eager to } \\
\text { learn more about my state. }\end{array}$ & 5 & 10 & 9 & 22 & 2 & 0 \\
\hline $\begin{array}{l}\text { I think about what I have } \\
\text { learned from other classes. }\end{array}$ & 2 & 6 & 6 & 12 & 8 & 4 \\
\hline $\begin{array}{l}\text { I look forward to earning } \\
\text { good grades. }\end{array}$ & 8 & 8 & 8 & 24 & 0 & 0 \\
\hline I study hard to pass tests. & 5 & 8 & 11 & 16 & 4 & 4 \\
\hline $\begin{array}{l}\text { I am excited to complete } \\
\text { projects and assignments. }\end{array}$ & 7 & 7 & 10 & 20 & 2 & 2 \\
\hline $\begin{array}{l}\text { I think about what topics } \\
\text { will be discussed next. }\end{array}$ & 4 & 4 & 16 & 8 & 8 & 8 \\
\hline
\end{tabular}

Table 6 shows the results of the Student Motivation Questionnaire administered to the class $(N=19)$ receiving direct instruction. Results show responses to many statements about motivation were consistent at both points of the study. At the beginning of the study, 10 students considered learning interesting and fun. At the end of the study, 11 students had the same regard for learning. The number of students who found content relevant, were confident and eager to learn more about their state, and were excited to complete projects and assignments only increased by 1 student after the intervention. Fifteen students believed they could learn through various kinds of activities at the beginning of the study, and 15 students believed the same at the conclusion of the study. 
Interestingly, the number of students who looked forward to earning good grades increased from 12 to 17 students at the end of the study. Considering the number of students who were undecided or disagreed with statements about being interested, being focused, being able to relate to content, and being confident to learn more about the state of GA, teachers must be aware that methods of instruction can have diverse effects on different students, and they must be cognizant of the impact of distinct learning activities on students' motivation.

Table 6

Questionnaire Results for Direct Group

\begin{tabular}{|c|c|c|c|c|c|c|}
\hline \multirow[b]{2}{*}{ Statements } & \multicolumn{3}{|c|}{ Before Intervention } & \multicolumn{3}{|c|}{ After Intervention } \\
\hline & Agree & Neutral & Disagree & Agree & Neutral & Disagree \\
\hline Learning is interesting and fun. & 10 & 6 & 3 & 11 & 8 & 0 \\
\hline $\begin{array}{l}\text { I can relate to what is being } \\
\text { taught. }\end{array}$ & 9 & 9 & 1 & 10 & 8 & 1 \\
\hline I am focused and interested. & 7 & 7 & 5 & 7 & 7 & 5 \\
\hline $\begin{array}{l}\text { I can learn through various } \\
\text { kinds of activities. }\end{array}$ & 15 & 2 & 2 & 15 & 2 & 2 \\
\hline $\begin{array}{l}\text { I am confident and eager to } \\
\text { learn more about my state. }\end{array}$ & 10 & 7 & 2 & 11 & 5 & 3 \\
\hline $\begin{array}{l}\text { I think about what I have } \\
\text { learned from other classes. }\end{array}$ & 5 & 8 & 6 & 5 & 5 & 9 \\
\hline $\begin{array}{l}\text { I look forward to earning } \\
\text { good grades. }\end{array}$ & 12 & 3 & 4 & 17 & 2 & 0 \\
\hline I study hard to pass tests. & 9 & 5 & 5 & 15 & 2 & 2 \\
\hline $\begin{array}{l}\text { I am excited to complete } \\
\text { projects and assignments. }\end{array}$ & 8 & 5 & 6 & 9 & 3 & 7 \\
\hline $\begin{array}{l}\text { I think about what topics } \\
\text { will be discussed next. }\end{array}$ & 4 & 9 & 6 & 8 & 7 & 4 \\
\hline
\end{tabular}

Results from the Student Engagement Checklist are shown in Tables 7 and 8. The checklist was given to students in both the literacy $(N=24)$ and the direct $(N=19)$ classes after 
the intervention. Engagement behaviors of students in the literacy class tended to increase as a result of the intervention. There were key differences between the literacy and direct students' responses regarding the incorporation of literacy strategies. Question 10 specifically asked students about being fully engaged. Results show the number of students responding sometimes or always increased, and the number of students indicating they were always engaged doubled. Other student responses reflect students in the literacy class indicated they interacted more with the teacher and other students and were on task more during instruction.

Table 7

Student Engagement Checklist Responses After Intervention

\begin{tabular}{|c|c|c|c|c|c|c|}
\hline \multirow[b]{2}{*}{ Response } & \multicolumn{3}{|c|}{ Literacy Class } & \multicolumn{3}{|c|}{ Direct Class } \\
\hline & Never & Sometimes & Always & Never & Sometimes & Always \\
\hline $\begin{array}{l}\text { 1. I interacted with other } \\
\text { students during class. }\end{array}$ & 0 & 12 & 12 & 2 & 17 & 0 \\
\hline $\begin{array}{l}\text { 2. I interacted with my } \\
\text { teacher during class. }\end{array}$ & 0 & 14 & 10 & 3 & 14 & 2 \\
\hline $\begin{array}{l}\text { 3. I participated in group } \\
\text { activities, reading, etc. }\end{array}$ & 0 & 16 & 8 & 7 & 12 & 0 \\
\hline $\begin{array}{l}\text { 4. I followed directions on } \\
\text { individual assignments. }\end{array}$ & 0 & 5 & 19 & 0 & 7 & 12 \\
\hline $\begin{array}{l}\text { 5. I was on task during } \\
\text { instructional activities. }\end{array}$ & 0 & 5 & 19 & 3 & 10 & 6 \\
\hline $\begin{array}{l}\text { 6. I was often thinking } \\
\text { about other things during } \\
\text { class. }\end{array}$ & 6 & 14 & 4 & 5 & 9 & 5 \\
\hline $\begin{array}{l}\text { 7. The teacher gave } \\
\text { specific feedback on tests } \\
\text { and projects, when I made } \\
\text { corrections/revisions to } \\
\text { my work. }\end{array}$ & 0 & 10 & 14 & 5 & 7 & 7 \\
\hline $\begin{array}{l}8 . \text { When I didn't } \\
\text { understand something, I } \\
\text { asked questions. }\end{array}$ & 6 & 12 & 6 & 1 & 9 & 9 \\
\hline $\begin{array}{l}\text { 9. I contributed to class } \\
\text { discussions and shared my } \\
\text { experiences. }\end{array}$ & 5 & 11 & 8 & 7 & 9 & 3 \\
\hline $\begin{array}{l}\text { 10. I was fully engaged } \\
\text { during lessons and } \\
\text { activities. }\end{array}$ & 0 & 8 & 16 & 4 & 7 & 8 \\
\hline
\end{tabular}


Journal of Social Studies Education Research 2016: 7(1), 73-95

More specifically, Table 8 shows mean comparisons of student engagement for the literacy class and the direct class. Students scored their engagement levels as 1 (never), 2 (sometimes), or 3 (always). The highest average rating per student was 30, and the lowest average rating per student was 10. A score closer to 30 reflected high levels of engagement, and a score closer to 10 indicated lower levels of engagement. The mean for the literacy class $(M=$ 27.92) was statistically significantly higher than the mean for the direct class $(M=19.84)$. A comparison of means of the ratings from the checklist from both classes $(p<.01)$ proved it was highly unlikely that the higher levels of engagement occurred by chance.

Table 8

Student Engagement Checklist Mean Comparison

\begin{tabular}{lcccc} 
Class & $N$ & $M$ & $t$-value & $p$ \\
\hline Literacy & 24 & 27.92 & 10.43 & .00002 \\
\hline Direct & 19 & 19.84 & & \\
\hline
\end{tabular}

The teacher-researcher observed students during instructional activities and recorded fieldnotes. Analysis of the data collected in those notes revealed that during instruction and class activities, students in the literacy class were more on-task than students in the direct class. Students in the direct class were more likely to exhibit poor work ethic on written assignments, talk and play during instruction, put their heads down on their desks, and fail to complete assignments. Students in the literacy class also seemed more attentive, asked questions, and were eager to complete collaborative and group activities, which rarely required them to use a traditional text. One student participant even commented, "I now see why social studies is so important.” During the study, no discipline infractions were recorded for the literacy class. Three discipline referrals were written for students in the direct class during the study. Findings from analysis of fieldnotes supported the statistical findings. 


\section{Discussion}

\section{Conclusions}

Did literacy strategies in GA Studies instruction affect achievement of eighth-grade students? The results from the use of all three instruments during the intervention indicated that incorporating literacy strategies does impact achievement in GA Studies. At the beginning of the study, both classes appeared to be at the same level of achievement. The pretest scores $(p<$ 0.14) of the literacy class and the direct class were not significantly different. Posttest scores between both classes, however, were significantly different. Mean gain comparisons showed that posttest scores were statistically higher $(p<.01)$ for students in the literacy class. The observed increase in student achievement is consistent with previous research by Bean and Dagan (2010), who found that effective literacy strategies are proven methods for improving instruction, achievement, and assessment. The findings also agree with Kent and Simpson (2008) who found that integrating literacy strategies increased students' achievement in social studies and strengthened skills that affect achievement in future social science classes.

Did the incorporation of literacy strategies increase student motivation during GA Studies? The use of literacy strategies in GA Studies did increase student motivation. At the end of the study, all students in the literacy group indicated in their responses that learning was interesting and fun. All participants in this class also viewed content as relevant, denoted they learned through the various collaborative activities, and looked forward to earning grades. Nearly all students indicated in their responses on the motivation questionnaire that they were confident and eager to learn more about their state. These findings are consistent with Reed (2009), who determined that using literacy strategies to make class experiences more relevant to students' interests, everyday life, or important current events motivates students because meaningful learning is taking place. Key et al. (2010) mentioned that we may be able to make students complete assignments, but we cannot compel them to care about what they are learning, but the current study did not support this assumption.

Are students in GA Studies classes more engaged when literacy strategies are incorporated into instructional activities? The results of the Student Engagement Checklist indicated students in the literacy class were more engaged than students in the direct class. A comparison of means of ratings on the checklist from both classes proved it was highly unlikely $(p<.01)$ that students were more engaged by chance. The results of the checklist further 
showed all of the students in the literacy class indicated in question 10 that they were sometimes or always fully engaged during instructional activities. These findings are consistent with Gross (2010), who concluded that using literacy strategies is a means for enhancing student engagement and is a viable way for helping students learn. It should be noted that off-task behaviors and discipline problems were recorded only for the direct class, and Key et al. (2010) found that such conduct often minimizes engagement when students deem instructional activities as boring, beyond their ability to understand, or disconnected from their personal experiences.

\section{Significance/Impact on Student Learning}

Students in the literacy class scored higher on the unit test and made greater gains on the posttest than did students in the direct class. The incorporation of literacy strategies could lead to increased achievement on future formative and summative assessments in Georgia Studies classes as well as on state mandated tests. The impact of literacy strategies in Georgia Studies was positive for the study population and caused students to be more motivated and engaged in learning activities in Georgia Studies. Students were also more involved, overall, in their own learning. Results show student interaction with the teacher and with classmates fostered collaboration.

\section{Factors Influencing Implementation}

There were several factors that could have influenced the implementation of this study. The direct GA studies class contained 2 English language learners (ELL). Language barriers could have been a hindrance to comprehension and learning for English language learners in the classes. Even though instructional activities and content focused on the state of Georgia, there was no guarantee students would have an endearment toward subject matter related to their home state. Some students in the class were not born or reared in Georgia and may have been disinterested because of that fact.

Another factor that could have influenced this study was the lack of a current Georgia Studies textbook, which was the main resource used to present content in the direct class. The text used was outdated, and some of the information in it conflicted with the information in the CRCT Test Prep workbook that was also used. Equally important were some students' initial perceptions of a social studies class. Because several students had not passed the previous year's social studies class or the social studies portion of the CRCT, they could have entered the class with an unfavorable attitude about learning in Georgia Studies. Also, because the pretest was 
given at the beginning of the school year, some students may have perceived the test as unimportant due to the fact that it was given before "real” instruction began.

\section{Implications and Limitations}

A significant difference in achievement and engagement between students in the literacy class versus students in the direct class provided evidence that the incorporation of literacy strategies can be a beneficial strategy. The findings of this study are consistent with the findings of most researchers, particularly in the area of literacy instruction in social studies or history classes. Most research supports the use of literacy strategies to teach social studies content. Therefore, the researcher will continue to use literacy instruction as part of a learner-focused Georgia Studies classroom.

The results of this study are significant for, but not limited to, social studies teachers, and lend credence to research on the effectiveness of embedding literacy strategies into instruction. Literacy strategies can be used across grade levels, as well as across academic disciplines. The higher achievement from using literacy strategies may lead to more project-based learning. The results of the motivation questionnaire and engagement checklist also offer suggestions teachers can use to make informed decisions about lesson planning, instructional practices and materials, and activities that will be more engaging for students. The findings of this study support a curriculum rich with technology, differentiated instruction, and collaborative learning.

Although the study did return a positive impact, there are limitations that must be addressed. The study was conducted over a 9-week period, which may not have been a sufficient length of time. It might have been more advantageous to monitor student achievement, motivation, and engagement throughout an entire school term. Other instruments such as semester exams, CRCT scores, and final grade point averages might be used to corroborate achievement findings.

Further research is needed to validate the finding of this study. Research including the use of literacy strategies with students with disabilities, gifted students, and students who have been retained may provide more conclusive results. More research should be conducted using other grade levels, other schools including other complex other academic disciplines, and with populations with different demographics for the results to be more reliable and generalizable. Also, using additional teachers to implement the intervention would decrease the potential for 
Journal of Social Studies Education Research 2016: 7(1), 73-95

bias in observations recorded in fieldnotes and would also allow multiple groups of student results to be analyzed.

\section{References}

Alberta Education. (2008). Supporting the literacy learner: Promising literacy strategies in Alberta. Alberta School Improvement Association Publications. Alberta, Canada.

Bayer, E. \& Staley, L. (2003). Literacy: The keys to success. Childhood Education, 79(4), 228-320.

Bean, R., \& Dagan, A. (2011). Best practices of literacy leaders: Keys to school improvement. New York: Guilford Press.

Blankenship, G. \& Wood, V. (2009). Georgia CRCT test prep: Teaching the Georgia performance standards. Atlanta: Clairmont Press.

Damico, J., Baildon, M., Exter, M., \& Guo, S. (2009). Where we read from matters: Disciplinary literacy in ninth-grade social studies classroom. Journal of Adolescent \& Adult Literacy, 53(4), 325-335.

Governor's Office of Student Achievement. (2011). 2010-2011 Report Card. Retrieved from http://gaosa.org/Report.aspx

Gross, P. (2010). Not another trend: Secondary-level literacy coaching. The Clearing House, 83(1), 130-137.

Hagood, M., Provost, M., Skinner, E., \& Egleson, P. (2008). Teachers’ \& students’ literacy performance in \& engagement with new literacy strategies in underperforming middle schools. Middle Grades Research Journal, 3(3), 57-95.

Kent, A., \& Simpson, J., (2008). Social studies and literacy integration: Making the most of our teaching. Social Studies Research and Practice, 3(1), 142-152. 
Key, L., Bradley, J., \& Bradley, K. (2010). Stimulating instruction in social studies. The Social Studies, 101(3), 117-120.

Lindsay, D., \& Horn, E. (2011). Strategies for supporting early literacy development. Young Exceptional Children, 14(3), 29-40.

Marzano, R., \& Pickering, D. (2005). Building academic vocabulary: Teachers manual. Alexandria, VA: ASCD.

Parr, M., \& Campbell, T. (2012). Understanding literacy as our world inheritance: Revisiting literacy discourse and its implications for teaching practice. International Review of Education, 58(4), 557-574.

Reed, D. (2009). A synthesis of professional development on the implementation of literacy strategies for middle school content area teachers. RMLE Online: Research in Middle Level Education, 32(10), 1-12.

Santamaria, L., Taylor, M., Park, T., Barett, K., \& Van der Mandele, E. (2010). Practical literacy matters: Teacher confidence is key. Techniques: Connecting Education and Careers, 85 (5), 45-47.

Soares, L. \& Wood, K. (2010). A critical literacy perspective for teaching and learning in social studies. The Reading Teacher, 63(6), 486-494.

U. S. Census Bureau. (2011). State and County Quick Facts. Retrieved from http://quickfacts.census.gov/qfd/states/13/13185.html 